SLOVO, sv. 68 (2018), 171-197, Zagreb 2018.

Kristijan KUHAR

UDK 27-528:811.163.1]"08/13"

Staroslavenski institut

Izvorni znanstveni članak

Zagreb

kristijan.kuhar@stin.hr

Primljen: 28. svibnja 2018.

Prihvaćen: 29. studenoga 2018.

\title{
UTJECAJ TEKSTOVA LATINSKIH RIMSKIH SAKRAMENTARA NA CRKVENOSLAVENSKU RIMSKU LITURGIJU (9. - 14. STOLJEĆEE)*
}

Liturgijski tekstovi crkvenoslavenskih sakramentara (Kijevski listići, Bečki listići, tzv. Sinajski misal - Sin. Slav. $5 N$ i dr.) ranoga razdoblja crkvenoslavenske rimske liturgije (od 9. do 14. stoljeća) pripadaju po svojem tekstološkom i euhološkom sadržaju rimskomu obredu. Riječ je o euhološkim tekstovima koji imaju liturgijsku funkciju: priređeni su i napisani za slavlje euharistije (mise), a sačuvani su u liturgijskoj knjizi nazvanoj sakramentar, odnosno misal. Rimska tekstološka liturgijska tradicija na latinskom jeziku prisutna u srednjovjekovnim sakramentarima dijeli se na dvije grane: gelazijevsku i grgurovsku, koje su se u sjevernoj Italiji i prekoalpskim zemljama (od Akvileje do Salzburga) miješale stvarajući novu tekstološku tradiciju, tzv. gelazijevsko-grgurovske sakramentare koji su korišteni na tom području.

Ovaj rad donosi istraživanje povijesti crkvenoslavenske rimske liturgije te povijesno-komparativnu analizu latinskih tekstova rimskoga obreda iz dostupnih izvora latinskih sakramentara i starocrkvenoslavenskih Kijevskih listića te hrvatskih crkvenoslavenskih Bečkih listića, Splitskoga fragmenta misala i Vatikanskoga misala Illirico 4. Na temelju istraživanja prikazuje se utjecaj latinske rimske liturgijske tekstološke tradicije na rane prijevode sakramentarā s latinskoga na starocrkvenoslavenski jezik (od 9. do 14. stoljeća) te na tekstove koji su tradicijom prešli u hrvatsko glagoljaštvo nakon reforme liturgijskih knjiga koncem 13. stoljeća i stvaranja liturgijske knjige »misal po zakonu rimskoga dvora«. Istraživanje je pokazalo da su se u prijevodima s latinskoga jezika na starocrkvenoslavenski jezik prevoditelji služili tekstovima rimskih latinskih sakramentara, čuvajući u prijevodima concinnitas i sobrietas Romana, tj. teološki izričaj euholoških tekstova rimskoga obreda. Prema tomu, nedvojbeno se može zaključiti da su najstariji prijevodi starocrkvenoslavenskih euholoških tekstova kao predložak imali rimske latinske tekstove s područja akvilejske crkvene jurisdikcije, salzburške nadbiskupije i krajevnih

* Ovaj rad dio je istraživanja doktorske disertacije (pars dissertationis) naslovljene Povijesno liturgijske posebnosti euholoških obrazaca ranog razdoblja slavenske liturgije (9. - 14. st.) $s$ osvrtom na predslovlja, napisane pod mentorstvom prof. dr. sc. Matea Žagara i prof. dr. sc. Ante Crnčevića na Poslijediplomskom doktorskom studiju medievistike na Filozofskom fakultetu Sveučilišta u Zagrebu, i obranjene 27. listopada 2017. godine. Dostupna je u repozitoriju Filozofskoga fakulteta Sveučilišta u Zagrebu. 
crkava koje su bile u doticaju s moravskim i panonskim područjem, kao i s hrvatskim i dalmatinskim crkvenim područjem.

Ključne riječi: crkvenoslavenska liturgija, hrvatski crkvenoslavenski jezik, rimski obred, Kijevski listići, Vatikanski misal Illirico 4

\section{UVOD}

Početci rane crkvenoslavenske liturgije ${ }^{1}$ datiraju se u početke misije svetih Konstantina Ćirila i Metoda u Moravsku, koja je prema historiografiji započela godine 863 . Iz bogate baštine te misije, koja je u srednjovjekovnoj crkvenoj i kulturnoj povijesti ostavila duboke tragove, razvija se tradicija liturgije na starocrkvenoslavenskom jeziku rimskoga i bizantskoga obreda. Iz samoga vremena misije Svete braće nisu sačuvani liturgijski izvori ${ }^{2}$ koji bi se mogli pripisati jednomu od njih dvojice, već jedino prijepisi liturgijskih izvora, a historiografski podatci i hagiografski navodi ne nude dovoljno podataka na koje bi se istraživač mogao osloniti. Zbog toga su početci ove liturgijske tradicije znanstveno zanimljivi, jer se tek interdisciplinarnim pristupom može dobiti cjelovita slika povijesnih događanja. U paleoslavistici još uvijek nije

1 Jedan je od ciljeva ovoga rada redefiniranje terminoloških odrednica. U paleoslavističkoj literaturi nailazimo na različite nazive koji bi mogli upućivati na krive zaključke, te će se govoriti o slavenskoj liturgiji, starocrkvenoslavenskoj liturgiji, glagoljskoj ili hrvatskoglagoljskoj liturgiji i slično. Odrednice koje ovim radom želimo postaviti odnose se na ispravno korištenje nazivlja, te će se zato koristiti nazivi poput crkvenoslavenska rimska liturgija kada se govori općenito o rimskoj liturgiji na starocrkvenoslavenskom jeziku ili na hrvatskom crkvenoslavenskom jeziku. Potom će se koristiti naziv starocrkvenoslavenska rimska liturgija kada će se opisivati liturgijski spomenici na starocrvenoslavenskom jeziku, ali rimskoga obreda. Korištenje naziva crkvenoslavenska liturgija u liturgijskoj znanosti može dovesti do nejasnoća i pogrešnih zaključaka. Naime, nije riječ o posebnom obredu, nego o liturgiji na starocrkvenoslavenskom jeziku koja se po provenijenciji i tipologiji sačuvanih izvora može pripisati bizantskomu ili rimskomu obredu. Kada naziv starocrkvenoslavenski ne stoji uz imenicu liturgija i njezine izvedenice, koristimo ga u vremenskom smislu, označavajući one izvore koji pripadaju kanonu starocrkvenoslavenskih izvora ili se datiraju prije kraja 12. stoljeća, a pisani su oblom glagoljicom ili starom ćirilicom. Slično tomu, naziv hrvatskoglagoljski odnosi se na izvore koji po svojim jezičnim odrednicama pripadaju hrvatskomu crkvenoslavenskomu jeziku, tj. hrvatskoj redakciji crkvenoslavenskoga jezika, pisani su uglatom (hrvatskom) glagoljicom te im se nastanak i uporaba može ubicirati na hrvatskom području i to nakon 12. stoljeća.

2 Liturgijski su izvori u ovom istraživanju prvenstveno liturgijski, tj. euhološki tekstovi, koji za razliku od biblijskih tekstova sačuvanih u glagoljskoj, starocrkvenoslavenskoj i crkvenoslavenskoj tradiciji mogu ukazati na smjerove podrijetla, utjecaja i miješanja. Euhološki su tekstovi molitveni obrasci koji se čitaju u liturgijskom slavlju euharistije ili drugih liturgijskih obreda, te nastaju pod utjecajima biblijskoga nadahnuća, slavlja određenoga blagdana i povijesnih prilika. 
postignut konsenzus niti je zaključeno istraživanje toga pitanja, a razlog tomu vjerojatno je činjenica da liturgijski tekstovi nisu sustavno istraživani metodama liturgijske znanosti, nego samo u domeni paleoslavističkih filoloških znanosti koje su iznjedrile vrijedan znanstveni doprinos.

Dosadašnja su povijesna istraživanja također iznjedrila vrijedne znanstvene zaključke. ${ }^{3}$ Ipak, u njima nema konačnoga odgovora na pitanje liturgijske provenijencije sačuvanih glagoljskih starocrkvenoslavenskih liturgijskih spomenika kao ni konkretnoga upućivanja na smjer utjecaja latinske rimske liturgijske tradicije na te prijevode. Tekstološka i liturgijska tradicija čiji su korijeni u vremenu inkulturacijske misije svetih Konstantina Ćirila i Metoda u 9. stoljeću ima svoj prirodni razvoj (engl. organic development), tj. transmisiju do vremena hrvatskoga glagoljaštva i početka čuvanja cjelovitih liturgijskih kodeksa. Dok za hrvatsko glagoljaštvo možemo utvrditi podrijetlo i liturgijsku tradiciju, za izvore rane crkvenoslavenske liturgije ${ }^{4}$ potrebno je $u$ istraživanje uključiti metode liturgijskih znanosti koje bi povijesno-komparativnim i povijesno-kritičkim metodama liturgijskih istraživanja donijele nove i vrijedne znanstvene zaključke i rezultate.

Istraživanja latinske liturgijske tradicije i njezinih vrijednih izvora već više od dva stoljeća donose nove činjenice koje pomažu u vrednovanju liturgijske prakse na različitim europskim prostorima pokazujući različitost tekstološke, ali jedinstvenost obredne tradicije. Temeljeći ova istraživanja na njima, nalazimo poticaj i za istraživanja crkvenoslavenske rimske liturgijske tradicije i otkrivanja novih rezultata o povezanostima i prožimanjima latinske i crkvenoslavenske obredne i tekstološke sličnosti ili, u nekim slučajevima, i različitosti.

$\mathrm{U}$ ovom radu, u sklopu istraživanja povijesti crkvenoslavenske rimske liturgije i povijesno-komparativne analize latinskih i crkvenoslavenskih tekstova, učinjenom za potrebe doktorske disertacije pod naslovom Povijesno liturgijske posebnosti euholoških obrazaca ranog razdoblja slavenske liturgije (9. - 14.st.) s osvrtom na predslovlja, prikazat ćemo utjecaj latinske rimske

3 Dosadašnja istraživanja pokazuju različite znanstvene doprinose, koji su vrijedni jer upućuju na određene znanstvene zaključke. Od recentnijih istraživanja možemo izdvojiti: BETTI 2014; DVORNIK 1956; DVORNIK 1970; DOSTAL 1965; GARZANITI 2007; GARZANITI 2010; LUKOVINY 2014; PENTKOVSKY 2014; ŠKOVIERA 2007. U navedena su istraživanja uključeni zaključci i drugih, pogotovo starijih istraživača.

4 Periodizacija crkvenoslavenske liturgije u ovom istraživanju donosi se prema tipologiji liturgijskih izvora. Razdoblje od 9. do početka 14. stoljeća nazivamo ranim razdobljem crkvenoslavenske liturgije. U tom razdoblju dolazi do jezične i obredne diferencijacije. Liturgijski tekstovi pisani su starocrkvenoslavenskim jezikom, tj. redakcijama crkvenoslavenskoga jezika i dijele se na rimski i bizantski obred. 
liturgijske tekstološke tradicije na rane starocrkvenoslavenske prijevode sakramentara (od 9. do 13. stoljeća), te na tekstove koji su tradicijom prešli u hrvatsko glagoljaštvo nakon reforme liturgijskih knjiga koncem 13. stoljeća.

\section{POVIJESNE ODREDNICE}

Početak ranoga razdoblja crkvenoslavenske liturgije određen je početkom inkulturacijske misije svetih Konstantina i Metoda te njihove književne i pisarske djelatnosti, prevođenja i prepisivanja liturgijskoga korpusa biblijskih i liturgijskih knjiga, pa sve do početka hrvatskoga glagoljaštva. Povijesna je pretpostavka da su slavenski narodi na prostoru Moravske i Panonije, među koje dolaze misionari sv. Konstantin Ćiril i Metod, kršćanstvo primili od zapadnih misionara koji su bili rimskoga obreda ${ }^{5}$ te da je takav obred ustanovljen na području srednjovjekovne Moravske, ali i Panonije te na području koje je graničilo s Istočnim Franačkim Carstvom. ${ }^{6}$

Pretpostavka je na koncu mnogih istraživanja da su prvotni misionari u Moravskoj i Panoniji sa sobom donijeli liturgijske knjige potrebne za redoviti život mjesne Crkve: sakramentare, ${ }^{7}$ lekcionare, evanđelistar te knjige za službu časova. Te liturgijske knjige mogle su biti predložak Svetoj braći da na tom misijskom području prevode rimske liturgijske knjige potrebne za redovito odvijanje crkvenoga života i to ponajprije sakramentare, lekcionare s rasporedom čitanja prema rimskomu obredu i dr. Vjerojatno je u korpusu latinskih rukopisa rimskoga obreda bilo i onih drugoga sadržaja, npr. raznih penitencijara i drugih knjiga potrebnih za osnovnu katehezu i obrede, čije tragove nalazimo u hrvatskom glagoljaštvu.

Ostaje pitanje kojoj su liturgijskoj tradiciji pripadale navedene latinske liturgijske knjige. Valja uzeti u obzir da 9. i 10. stoljeće za povijest liturgije predstavlja razdoblje u kojem se rimske liturgijske knjige prilagođavaju fra-

5 Pitanje kristijanizacije Moravske dotiče se arheoloških i povijesnih istraživanja. O tom vidi DVORNIK 1970 i BETTI 2014. Vidi također KOUŘIL 2014. Žitje Metodovo navodi: Et venerunt ad nos doctores christiani multi ex Italia et e Graecia et e Germania, docentes nos diverso modo; verum nos Sloveni rudes homines et non habemus, qui nos instituat in veritate et sensum explicet. (ŽM V, 2).

6 Povijesni izvori, koji su prisutni u recentnim istraživanjima, kao i u sklopu Magnae Moraviae Fontes Historici, ne donose pitanje obreda koji je bio prisutan na navedenom području, nego samo pitanje crkvene i političke jurisdikcije. F. Dvornik i M. Betti u svojim se radovima tek sporedno dotiču pitanja obreda, temeljeći svoja istraživanja na pitanju uspostave crkvene hijerarhije i uređenja. Vidi više: BETTI 2014; DVORNIK 1956; DVORNIK 1970.

7 Sakramentar je liturgijska knjiga koja je sadržavala tekstove molitvi (euhološke tekstove) za slavlje euharistije. U rimskoj tradiciji tekstno se razlikuju gelazijevska i grgurovska tradicija sakramentara. 
načkim utjecajima te ne postoji jedinstvenost tekstne tradicije latinskih sakramentara rimskoga obreda. Svakako valja voditi računa o dodirnom području s kojega su misionari dolazili kao i o tom koje su liturgijske knjige latinske tradicije bile u uporabi na tom području. Srednjovjekovni prostor zapadne Crkve nije bio jedinstven u liturgijskoj tekstnoj tradiciji do 12. stoljeća te su kružile knjige različitoga liturgijskoga, ponajprije tekstološkoga, ali ne i obrednoga sadržaja.

Dolaskom u Moravsku sveti Konstantin Ćiril i Metod sa sobom donose liturgijske knjige bizantskoga obreda,${ }^{8}$ što je razumljivo jer su u misiju poslani kao misionari bizantskoga cara, a prema tomu i bizantske Crkve. Svakako, uzimajući u obzir dosadašnja lingvistička paleoslavistička istraživanja, možemo zaključiti da se radi o bizantskom obredu u korpusu onih liturgijskih knjiga koje su služile za službu Riječi u liturgiji, no ako pogledamo euhološke tekstove, nailazimo na drugačiji zaključak. Liturgijske knjige za službu Riječi sadržavaju ili svetopisamske tekstove u cjelovitosti, poput tzv. tetraevanđelja i psaltira, ili njihove odlomke, poput evanđelistara i lekcionara u rimskoj liturgiji. Euhološki (ili molitveni) tekstovi nalaze se u sakramentarima i obrednicima (ritualima ili euhologijima), no ti tekstovi ne pripadaju Svetomu pismu, već su djelo određenoga autora, redovito crkvenoga oca ili nekoga biskupa, nadahnuti riječima Svetoga pisma.

Starocrkvenoslavenski kanonski spomenik za koji se može odrediti da pripada rimskomu obredu jesu Kijevski listići. Sinajski sakramentar, Bečki listići i Sinajski fragment sakramentara (Fragmentum liturgiarii Sinaiticum) sadrže, doduše, kao i Kijevski listići, euhološke tekstove rimskoga obreda, ali nisu ušli u kanon starocrkvenoslavenskih spomenika. Ti su spomenici pak fragmenti libellus missae ili sakramentara rimskoga obreda, dok se za obredne tekstove prisutne u Sinajskom euhologiju može zaključiti da pripadaju istočnomu, bizantskomu obredu. Euhološki tekstovi iz sakramentara provlače se u transmisiji teksta do vremena zreloga hrvatskoga glagoljaštva, kao i tekstovi različitih obreda, koji nisu bili izravno rimski, a sadržani su u brojnim hrvatskoglagoljskim misalima. ${ }^{9}$

Rano se razdoblje crkvenoslavenske liturgije tako grana na dvije grane: prva je rimska liturgijska tradicija, koja svoje izvore ima u kanonskim starocrkvenoslavenskim izvorima, a nazivamo ju crkvenoslavenska rimska liturgija,

\footnotetext{
${ }^{8}$ Žitja Konstantina Ćirila i Metoda ne navode s preciznošću koje su liturgijske knjige prevedene. Ali se može zaključiti da Solunska braća, odgojena i odrasla u okružju istočne crkvene uljudbe, sa sobom nose liturgijske knjige istočnoga, tj. bizantskoga obreda. Tek navod iz Žitja Konstantina Ćirila XIV,13 da evanđelistar počinje riječima Proslova evanđelja po Iva$n u$ može ukazati na liturgijsku knjigu bizantskoga obreda.

9 Za ritualne tekstove vidi TANDARIĆ 1980.
} 
a druga je bizantska liturgijska tradicija koja svoje izvore ima u ćirilometodskim prijevodima, ali je sačuvana u prijepisima mlađega razdoblja - vjerojatno nakon dolaska učenikā Svete braće na područje pod utjecajem bizantske Crkve, tj. u Bugarsku i Makedoniju, te ju nazivamo crkvenoslavenska bizantska liturgija.

\section{POVIJESNE OKOLNOSTI NASTANKA CRKVENOSLAVENSKE LITURGIJE I PITANJE OBREDNE PRIPADNOSTI}

Povijesno istraživanje nastanka crkvenoslavenske rimske liturgije otvara pitanja s više znanstvenih područja: povijesti, crkvene povijesti, liturgije, povijesti književnosti, povijesti jezika i dr. Pitanje kojemu je posvećen ovaj dio istraživanja glasi: koliko su rimski latinski sakramentari utjecali na stvaranje starocrkvenoslavenskih liturgijskih tekstova? U traženju odgovora na njega valja provjeriti povijesne i hagiografske podatke kao i same liturgijske izvore navedenoga razdoblja. ${ }^{10}$ Malo je kvalificiranih povijesnih izvora o nastanku crkvenoslavenske rimske liturgije. Povijesni se dokumenti ponajprije odnose na korespondenciju rimskih prvosvećenika s crkvenom i političkom vlašću područja Moravske i Panonije, ${ }^{11}$ te na Žitija svetih Konstantina Ćirila i Metoda (ŽK i ŽM).

Prvi tragovi papinske korespondencije datiraju u godinu 867., pozivom pape Nikole I. Svetoj braći da dođu u Rim. ${ }^{12}$ Sljedeći dokumenti potječu iz 869. godine, a odnose se na pisma pape Hadrijana II. panonskomu knezu Kocelju, ${ }^{13}$ odnosno iste godine knezu Rastislavu, Svatopluku i Kocelju. ${ }^{14}$ Pismo pod naslovom Gloria in altissimis Deo sačuvano je u starocrkvenoslavenskom prijevodu u ŽM, poglavlje VIII. U tom pismu, koje se predstavlja kao prvo koje potvrđuje uporabu starocrkvenoslavenskog jezika u liturgiji, papa Hadri-

\footnotetext{
${ }^{10}$ Opsežnijom se analizom bavim u doktorskoj disertaciji. Ovdje donosim samo važnije povijesne i hagiografske dokumente.

${ }^{11}$ Historiografski podatci sabrani su u zbirci Magnae Moraviae Fontes Historici (MMFH), posebno u svescima II. i III.

${ }^{12}$ Usp. MMFH III, B. 34.

${ }^{13}$ Vidi MMFH III, B. 38.

${ }^{14}$ Usp. MMFH III, B. 39. Ondje papa napominje da su Sveta braća poslana u Moravsku iz Bizanta, darom cara Mihaela III, jer Sveta Stolica nije dospjela poslati svoje misionare, te da Sveta braća - svjesna apostolske jurisdikcije - nisu htjela učiniti ništa protivno kanonima, već su došla papi noseći relikvije svetoga Klementa I. pape. Oni su pak, navodi papa:

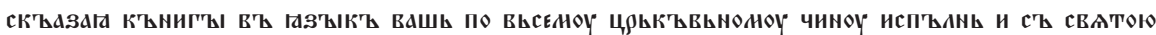

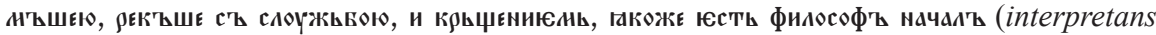
libros in linguam vestram, secundum totum ecclesiasticum ordinem plene et cum sancta missa (id est liturgia) et baptismo, quemadmodum copererat philosophus Constantinus), prema ŽM VIII, 11.
} 
jan II. određuje da se poslanica i evanđelje čitaju najprije latinskim, a potom starocrkvenoslavenskim jezikom. Interes rimskih prvosvećenika u pismima koja navodimo ne odnose se toliko na pitanje discipline obreda, koliko na potvrdu rimske jurisdikcije nad područjem Moravske i Panonije, tj. istočnim Ilirikom, koji je Bizant uzurpirao gotovo stoljeće prije. ${ }^{15}$

Korespondencija rimskih prvosvećenika nakon Hadrijana II., ponajprije ona Stjepana V. i Ivana VIII., dotiče se iste problematike. Pitanje obreda ne dolazi do izražaja jer se pretpostavlja da je na prostoru rimske jurisdikcije prisutan rimski obred. Problem stvara tek pitanje liturgijskoga jezika jer se starocrkvenoslavenski pojavljuje kao ravnopravan latinskomu liturgijskomu jeziku. Godine 880. papa Ivan VIII. piše knezu Svatopluku pismo pod naslovom Industriae tuae. Ondje papa navodi ključne podatke za pastirsko djelovanje sv. Metoda te potvrđuje pripadnost njegove nadbiskupije, kao i cijele moravske kneževine, apostolskoj stolici. Papa piše: Ille (Methodius) autem professus est se iuxta evangelicam et apostolicam doctrinam, sicuti sancta Romana ecclesia docet et a patribus traditum est, tenere et psalere. Nos autem illum in omnibus ecclestiasticis doctrinis et utilitatibus orthodoxum et proficuum esse repperientes ... (MMFH III, B. 90). Papa potvrđuje Metodovu katoličku pravovjernost i privrženost rimskoj apostolskoj stolici i nauci. Dalje $\mathrm{u}$ istom pismu Ivan VIII. spominje i pitanje pisma i jezika: Litteras deinque Sclavinicas a Constantino quondam philosopho repertas, quibus Deo laudes debite resonent, iure laudamus et in eadem lingua Christi domini nostri preconia et opera enarrentur, iubemus. (MMFH III, B. 90). Te dalje: Nec sane fidei vel doctrinae aliquid obstat sive missas in eadem Sclavinica lingua canere sive sacrum evangelium vel lectiones divinas novi et veteris testamenti bene translatas et interpretatas legere aut alia horarum officia omnia psallere (...) Iubemus tamen, ut in omnibus ecclesiis terrae vestrae propter maiorem honorificientiam evangelium Latine legatur et postmodum Sclavinica lingua translatum in auribus populi Latina verba non intelligentis adnuntietur, sicut in quibusdam ecclesiis fieri videtur. (MMFH III, B. 90). Papa Ivan VIII. ponovno potvrđuje starocrkvenoslavenski jezik u bogoslužju, držeći se zaključka pape Hadrijana II. zapisanog u pismu Gloria in altissimis, a spominje i običaj koji je već uvriježen u nekim crkvama. Time i papa Ivan VIII. starocrkvenoslavenski jezik postavlja kao lingua sacra rimskoga obreda.

Stajalište papinstva prema starocrkvenoslavenskom jeziku u liturgiji mijenja se dolaskom pape Stjepana V. U pismu knezu Svatopluku godine 885., naslovljenom Quia te zelo fidei, papa zabranjuje starocrkvenoslavenski jezik

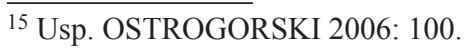


u liturgiji ${ }^{16}$ ostavljajući ga kao mogućnost tek neukima (simplicis populi et non intelligentis). Papa mijenja i crkvenu politiku prema Moravskoj i Panoniji, oslanjajući se više na franački kler, čime otvara put progonu Metodovih učenika i zatiranju glagoljaštva na području Moravske i Panonije.

$\mathrm{Na}$ temelju povijesnih izvora ne nalazimo podatke koji bi upućivali na izvorni obred preveden na starocrkvenoslavenski jezik, već samo na problematiku liturgijskoga jezika. Latinski je jezik nastojanjima oko ujednačavanja rimskoga obreda u tom povijesnom razdoblju postao lingua sacra rimske Crkve te je to ostao do danas. ${ }^{17}$ Stoga na temelju povijesnih izvora ne možemo izričito potvrditi kojemu je obredu pripadala slavenska liturgija ranoga razdoblja, što nas nužno upućuje na potrebu istraživanja samih liturgijskih izvora.

Premda se pojavljuju u različitim inačicama prijepisa tek od 15. stoljeća, hagiografski izvori, Žitija svetih Konstantina Cirila i Metoda, sadrže neke podatke koji mogu upućivati na pitanje obreda. Iako se uzimaju s određenom znanstvenom zadrškom, sadrže i određene povijesne podatke kojima se potvrđuju činjenice svetosti i izvanrednosti života sveca o kojem pišu.

Hagiografi ne navode izričito koji je obred bio u uporabi, ali spominju ove

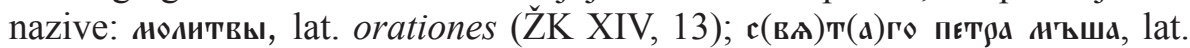
sancti Petri missa (id est liturgia) (ŽM XI, 4.); ц९ъковныии чинъь, оүтрєнїи,

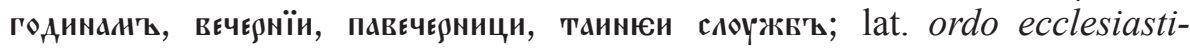
cus, officium matutinum, horas, vesperas, completorium, mystica liturgia, missa (ŽK XV, 2.); иитоүргї̈, lat. sancta liturgia (ŽK XVII, 5; XVII, 7); $\mathfrak{c}($ вА)тою възиношению танною, lat. sanctam oblationem mysticam (ŽM XV,

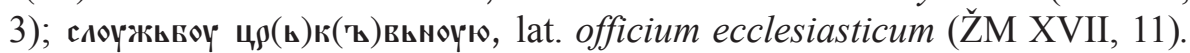
$\mathrm{Na}$ temelju nazivlja dobiva se dojam da je hagiograf namjerno navodio terminologiju koja je bila korištena za oba obreda, tj. za bizantski i za rimski.

Pitanje obreda kojemu je pripadala rana slavenska liturgija ne donosi se ni u povijesnim ni u hagiografskim dokumentima. Uzrok je tomu činjenica da se obred na području rimske jurisdikcije vjerojatno pretpostavljao sam po sebi. Bio je, očito, rimski. Sporan je bio jedino liturgijski jezik koji je zbog nerazumijevanja, ali i zbog latinizacije rimske liturgije u tom vremenu predstavljao i crkveni i politički problem.

${ }^{16}$ Divina autem officia et sacra mysteria ac missarum sollemnia, quae idem Methodius Sclavorum lingua celebrare preaesumpsit, quod, ne ulterius faceret, super sacratissimum beati Petri corpus iuramento firmaverat, sui periurii reatum perhorescentes nullo modo deinceps a quolibet praesumatur, Dei namque nostraque apostolica auctoritate sub anathemis vinculo interdicimus, excepto quod ad simplicis populi et non intelligentis aedificationem attinet, si evangelii vel apostoli expositio ab eruditis eadem lingua annuntietur, et largimur et exhortamur et ut frequentissime fiat monemus, ut omnis lingua laudet Deum et confiteatur ei. MMFH III, B. 101.

${ }^{17}$ Linguae latinae usus, salvo particulari iure, in Ritibus latinis servetur. SC 36, 1. 
Odgovor na pitanje kojega je obreda bila rana slavenska liturgija mogu dati upravo liturgijski izvori koji sadrže euhološke elemente. U ovom istraživanju dotičemo se tek nekoliko liturgijskih izvora koje ćemo usporediti s latinskim rimskim sakramentarima toga doba kako bismo utvrdili pripadnost obreda i utjecaj latinskih rimskih sakramentara na starocrkvenoslavenske i hrvatske crkvenoslavenske liturgijske izvore.

\section{LATINSKE LITURGIJSKE KNJIGE - RAZNOLIKOST RIMSKE TRADICIJE U 9. STOLJEĆU}

U ovom istraživanju koristili smo povijesno-komparativnu i povijesno-kritičku metodu istraživanja. Da bismo utvrdili koje su liturgijske provenijencije bile starocrkvenoslavenske liturgijske knjige, posegnuli smo za usporedbom s rimskim liturgijskim knjigama, kao povijesno-komparativnim materijalom.

Liturgijske knjige rimske obredne tradicije u povijesnom razdoblju od 9. do 13. stoljeća, kada se razvija crkvenoslavenska rimska liturgija, nisu bile jedinstvene sve do početka širenja obrednoga oblika secundum consuetudinem Romanae curiae. Srednjovjekovni pokušaji unutar tzv. merovinške i karolinške »renesanse« bili su vrsni primjeri kako su svjetovni vladari uz pomoć Crkve nastojali ustaliti i stvoriti jedinstveni obred na prostoru svoje vlasti. No i unatoč sličnim pokušajima na širokom prostoru franačkoga carstva, te se namjere nisu uspjele u potpunosti ostvariti. ${ }^{18}$

Premda postoje razni znanstveni zaključci o evoluciji rimskoga obreda te o njegovoj tekstološkoj raznolikosti, valja zapaziti da sačuvani primjerci liturgijskih knjiga pisanih na latinskom jeziku otkrivaju smjerove kretanja i utjecaja kao i obredne uporabe u određenom vremenskom razdoblju. Zasigurno da isti sakramentari nisu korišteni u Rimu kao i u Aachenu, Salzburgu ili u drugim krajevima kršćanskoga zapadnog Carstva. U samom Rimu supostoje gelazijevska i grgurovska tekstološka tradicija, koja je sačuvala euhološki poklad za slavlja euharistije i druge sakramente prema uobičajenomu rimskomu Ordo. ${ }^{19}$ Te tekstne tradicije određuju i tip sakramentara kakav je korišten u rimskoj Crkvi prije nastanka plenarnih misala. ${ }^{20}$

\footnotetext{
${ }^{18}$ Za povijesni pregled vidi DIX 1949; NEUNHEUSER 2009.

19 Tipologiju sakramentara objašnjavaju VOGEL 1986; GAMBER 1968; NEUNHEUSER 1992. O najstarijim knjigama rimskoga obreda te o tipološkom razvoju vidi JUNGMANN 2012.

${ }^{20}$ Vidi: NEUNHEUSER 2009: 98-99 i VOGEL 1986: 70. Razlika između gregorijanskoga i Gelazijeva sakramentara jest i u sadržaju. Na primjer, Gelazijev sakramentar imao je dvije zborne molitve, tj. dvije molitve prije darovne molitve. Usp. VOGEL 1986: 75. O Gelazijevu sakramentaru vidi također: DIX 1949: 565. Dix napominje da je Gelazijev sakramentar korišten u Sjevernoj i Istočnoj Franačkoj te Engleskoj prema sačuvanim fragmentima rukopisa.
} 
Gelazijevska tekstološka i liturgijska tradicija starija je i prema povjesničarima liturgije bila je namijenjena uporabi u rimskim titularnim crkvama. To je ujedno prva liturgijska i tekstološka tradicija koja već u 8. stoljeću prelazi granice Rima te se rabi u franačkoj kulturnoj i crkvenoj domeni. ${ }^{2 i}$

Grgurovska tekstološka i liturgijska tradicija namijenjena je papinskoj liturgijskoj praksi te je tijekom svojega postojanja prolazila različite faze promjena i uporabe. Autorstvo joj je pripisano papi Grguru Velikomu, premda su i drugi pape itekako utjecale na njezin tekstološki i liturgijski sastav. Poznato je da je upravo primjerak Grgurova sakramentara, koji se naziva i Hadrijanov (Gregorianum-Hadrianum), poslan u Aachen 784. - 785. godine s nakanom da postane redovita i jedinstvena liturgijska knjiga franačkoga carstva. Ta je liturgijska tekstološka tradicija u više svojih inačica utjecala na razvoj euhologija koji je kasnije našao kontinuitet u rimskim misalima sve do našega vremena. ${ }^{22}$

Uz te dvije tradicije (tekstološku i liturgijsku) postojala je i ona treća - miješana, mixta, koja se proširila na područjima koja su bila dovoljno daleko od centara duhovne i svjetovne moći, npr. u sjevernoj Italiji (Akvileja), te u Bavarskoj i zemljama koje su bile dodirna područja s novopokrštenim slavenskim narodima. ${ }^{23}$ Vjerojatno su se takvim sakramentarima služili latinski misionari koji su donijeli sjeme kršćanstva u Moravsku i Panoniju. Kao što je već rečeno, rimski je obred, premda na latinskom jeziku, bio poznat pokrštenim Slavenima Panonije i Moravske. Tim tezama, koje se vežu za povijest Crkve i za određene teološke postavke, svakako treba uključiti i arheološka istraživanja koja mogu

\footnotetext{
${ }^{21}$ Najstariji primjerak gelazijevskog sakramentara sačuvan je u primjerku Codex Vaticanus Reginensis Latinus 316, poznatom pod nazivom Sacramentarium Gelasianum Vetus. Opis donosi CLLA 610: 301. Gelazijevski su sakramentari bili raspoređeni u tri dijela s odvojenim liturgijskim slavljima kroz liturgijsko vrijeme, slavlja svetaca i kanon mise s misnim obrascima za nedjelje, zavjetnim misama te drugim molitvenim obrascima. Namjena im je bila za slavlje liturgije u rimskim titularnim crkvama. Njegova je tekstološka karakteristika broj euholoških elemenata: ima dvije molitve na početku euharistijskoga slavlja, tzv. oratio collecta, zatim molitvu nad darovima, tzv. oratio secreta i oratio post communionem. Pretpostavka je povjesničarā liturgije da je Gelazijev sakramentar prenesen u Franačku u 7. stoljeću, gdje je obogaćen dodatcima franačkoga podrijetla. Za više vidi VOGEL 1986: 64-78.

${ }^{22}$ Grgurovski sakramentari oblikovani su kao jedan kodeks u kojem je sav liturgijski sadržaj raspoređen prema liturgijskoj godini, svetačkim slavljima i posebnim obredima. Euhološki su obrasci jednostavniji od Gelazijeva sakramentara. Sadrže samo tri molitve i predslovlje te dodatnu molitvu u korizmenom vremenu (oratio collecta, super oblata, ad completa / ad complendum i super populum). U tekstološkoj tradiciji grgurovskih sakramentara posebno se ističu tipovi koji su dopunjeni vlastitostima franačke i drugih lokalnih crkava, a takvi su rukopisi u prijepisima bili prisutni u dodirnom području sa slavenskim crkvenim teritorijem. Među njima se ističu: Gregorianum Hadrianum sa Supplementumom, Gregorianum Paduense, Gregorianum Tridentinum. Svaki navedeni tip predstavlja nastavak tekstološke i liturgijske tradicije srednjega vijeka i evolucije liturgijskih knjiga. Za više vidi VOGEL 1986: 79-105.

${ }^{23}$ Usp. VOGEL 1986: 103. CLLA navodi u br. 397, 630, 735-736, 830, 880, 883.
} 
dati pravovaljani odgovor na obrednu atribuciju u srednjovjekovnim slavenskim kneževinama, tj. uzeti u obzir i arheološka istraživanja liturgijske arhitekture, koja su neizostavna za ispravno razumijevanje povijesti.

Istraživanja latinske tekstološke i liturgijske tradicije u posljednja dva stoljeća pokazala su koji su sakramentari i koja je liturgijska tradicija bila prisutna na dodirnim područjima krajevnih crkava. U euhološkim tekstovima sadržanim u sakramentarima nalaze se odgovori na mnoga istraživačka pitanja. Uzimajući u obzir ranija istraživanja Klausa Gambera (GAMBER 1966) i drugih, otkrivaju se sakramentari salzburške nadbiskupije, kao i sakramentari koji su bili u uporabi u crkvama akvilejskoga crkvenoga područja. Gamber ih u katalogu Codices liturgici Latini antiquiores navodi kao tip sakramentara Paduense (tip P), koji se rabio na području sjeverne Italije, tj. akvilejskoga patrijarhata u 8. i 9. stoljeću. $^{24}$

Osim Padovanskoga sakramentara (Sacramentarium Paduense), Gamber u kontaktno područje smješta Fragment salzburškog sakramentara s početka 9 . stoljeća, ${ }^{25}$ za koji navodi da je tekstološki sličan Kijevskim listićima (FgKij).

Glagoljske starocrkvenoslavenske fragmente, Kijevske i hrvatske crkvenoslavenske Bečke listiće isprva smješta u korpus grgurovskih sakramentara tipa P (Paduense), pod br. 895. i 898. U novom izdanju (koje supotpisuju Baroffio, Dell'Oro, Haenggi, Janini i Triacca) Kijevski su listići označeni kao libellus missae unutar tipa Paduense grgurovske tekstne tradicije, ali uz sakramentare koji potječu sa sjevernotalijanskoga područja. ${ }^{26}$ Upravo taj sud danas

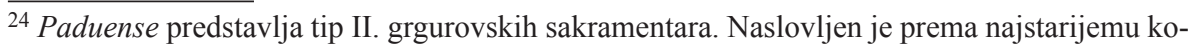
deksu koji se nalazi u padovanskoj kapitularnoj knjižnici (Biblioteca capitulare), s oznakom codex D. 47. Tekstni mu je sadržaj identičan Grgurovo-Hadrijanovu, ali s vlastitostima: kanon mise na kraju kodeksa, sedam misa za svagdane (missae cottidianae Gregorii papae). Neke liturgijske tekstove preuzima iz Gelazijeva sakramentara. Vidi: VOGEL 1986: 97. Njegova je važnost u tom što je korišten na području sjeverne Italije, akvilejskoga patrijarhata i njegovih sufraganskih biskupija. Slični su mu i Salzburški sakramentar, fragment sakramentara iz Reichenaua i Kijevski listići. Usp. VOGEL 1986: 97; GAMBER 1968: 400-406; CLLA 883, 885, 895. Više o Paduense vidi u CLLA 880.

${ }^{25}$ Kratica Sal u CLLA 883.

${ }^{26}$ Posebno je vrijedno zapaziti da Gamber nastanak i uporabu sakramentara tipa P povezuje s akvilejskim patrijarhatom (usp. CLLA 397). Područje akvilejskoga patrijarhata dodirno je područje rane crkvenoslavenske liturgije, a isto vrijedi i za sakramentare koji pripadaju ovome tipu. Među njima je Padovanski sakramentar D 47 (usp. CLLA 880), Salzburški sakramentar (navodi i tip Sal, CLLA 883) kao i naši starocrkvenoslavenski, Kijevski (CLLA 895), i hrvatski crkvenoslavenski Bečki (CLLA 898) listići. Salzburški, Praški i Padovanski sakramentar korišteni su na području akvilejskoga patrijarhata, odnosno na području od sjeverne Italije do Regensburga, od Bodenskoga jezera do Panonije. Gamber napominje da je sakramentar salzburškoga tipa bio službena liturgijska knjiga akvilejskoga patrijarhata. Usp. GAMBER 1966: 209-213. 
vodećega povjesničara liturgije daje nam zaključiti da se dodirno područje starocrkvenoslavenske i latinske liturgijske tradicije nalazi upravo u tradiciji sjevernotalijanskih, tj. prekoalpskih liturgijskih i tekstoloških izvora.

Tekstološke sličnosti sa starocrkvenoslavenskim liturgijskim izvorima pokazuju i grgurgovski miješani sakramentari (Sacramentaria Gregoriana mixta, 9. - 11. st.), iz čije se tekstološke tradicije izdvaja skupina Sacramentaria Fuldensia koja je također prisutna na dodirnom području slavenske i latinske tradicije. Unutar toga tipa Gamber smješta i Salzburški sakramentar (CLLA 980., poč. 11. st.) te Fragment salzburškoga sakramentara (CLLA 981., kraj 10. st.). Gregoriana mixta tekstološka je liturgijska tradicija koja u jezgri sadrži i tekstove koji potječu iz gelazijevske tradicije. Na prostorima bavarske krajevne Crkve nastao je i Sakramentar iz Praga, tzv. Tassilo sakramentar (Pr: CLLA 630., kraj 8. st.), koji se ne može izravno povezati sa starocrkvenoslavenskim izvorima, ali on još nije do kraja istražen. Budući da su korišteni na dodirnom području s Moravskom i Panonijom, tj. u dijecezama koje su utjecale na područje ćirilometodske misije, sakramentari, odnosno opisani tipovi sakramentara mogu biti pokazatelji liturgijske tradicije koja je u temeljima rane crkvenoslavenske liturgije.

Navedeni kratki pregled tekstološke liturgijske tradicije pokazuje koliko je zapravo prostor rimskoga obreda bio neujednačen te je svaka atribucija i afilijacija zapravo nemoguća bez kvalitetnoga istraživanja ponajprije rimske liturgijske tradicije i povijesno-komparativne analize cjelokupnoga sačuvanoga korpusa. I sama povijesno-komparativna analiza može pomoći u otkrivanju tipologije kontaktnih sakramentara, tj. sličnosti euhološkoga poklada koji je bio predložak prevođenju na starocrkvenoslavenski jezik u 9. - 11. stoljeću.

U ovom istraživanju nećemo ulaziti u pojedinosti sakramentara, već ćemo prema tekstološkoj i komparativnoj analizi pokazati tekstološke sličnosti s određenim sakramentarima uspoređujući starocrkvenoslavenske izvore s latinskim. Također ćemo istražiti tekstnu tradiciju do pojave najstarijega hrvatskoglagoljskoga misala, Vatikanskoga misala Illirico 4 (MVat ${ }_{4}$ ).

\section{CRKVENOSLAVENSKI LITURGIJSKI IZVORI}

Za cjelovito istraživanje utjecaja latinskih sakramentara na crkvenoslavenske liturgijske izvore učinjena je šira analiza, a ovdje donosimo istraživanje samo odabranih izvora. Izvori za istraživanje nisu izabrani nasumično, nego logičkim redom prema starini i tipologiji. ${ }^{27}$ Kijevski listići i Bečki listići

\footnotetext{
${ }^{27}$ Tipologija kojom smo se vodili prema CLLA, br. 405 i 405/6. gdje su FgKij i FgVind afilirani sakramentarima.
} 
tipološki su određeni kao odlomci sakramentara ili odlomci libellus missae, dok je Splitski fragment misala tipološki određen kao odlomak misala starije redakcije od $\mathrm{MVat}_{4}$.

Kijevski listići (FgKij) najstariji su glagoljični kanonski spomenik starocrkvenoslavenskoga jezika. Napisani su oblom glagoljicom. Datiraju se u 10./11. stoljeće, a ubiciraju na područje Moravske i Panonije. ${ }^{28}$ Prema liturgijskoj su tipologiji primjerci libellus missae. Sadrže devet euholoških obrazaca i sedam predslovlja, dok tekst euharistijske molitve ne sadrže. ${ }^{29} \mathrm{Njemač-}$ ki povjesničar liturgije Cunibert Mohlberg među prvima je opisao liturgijski sadržaj FgKij u komparativnoj liturgijskoj analizi. Starinu FgKij odredio je uzimajući u obzir zaključke istraživanja Sreznjevskoga, Geitlera i Jagića, ${ }^{30}$ smještajući ih u 11. stoljeće s uvjerenjem da njihov prototip potječe iz vremena Svete braće. Oslanjajući se na ranije Jagićeve zaključke, ${ }^{31}$ Mohlberg Kijevske listiće smješta u vrijeme kada glagoljaštvo prelazi u službu rimskoga obreda. ${ }^{32}$ Prostorno ih veže za »transdanubijske prostore«, a Bečke listiće na »cisdanubijske«. Mohlberg tvrdi da uzorak iz kojega su prevedeni FgKij pripada identičnomu tipu kao i Padovanski sakramentar D $47 .^{33}$

Bečki listići (FgVind), kao i Kijevski listići, prema liturgijskoj su tipologiji fragment libellus missae, tj. "glagoljički palimpsest od dvaju pergamentnih listova u formatu male osmine, kojemu stariji glagoljički tekst u podlozi nikad nije pročitan« (ŽAGAR 2005: 143). Pisani su uglatom glagoljicom i smatraju se jednim od najstarijih spomenika hrvatskoga crkvenoslavenskoga jezika. Datacija je ovoga spomenika 12. stoljeće, a ubikacija zapadni prostor hrvatskoga glagoljaštva. ${ }^{34}$ Agnezija Pantelić za FgVind tvrdi da »predstavlja u evoluciji latinskih sakramentara obogaćeni staroslavenski sakramentar, jer uz oracije i prefacije Kijevskih listića ima i čitanje poslanice (1 Kor 4, 9-16)《 (PANTELIĆ 1986: 100).

Splitski fragment misala (FgSpal) također je pisan uglatom glagoljicom i hrvatskim crkvenoslavenskim jezikom. Znanstveno ga je obradio Vjekoslav

\footnotetext{
${ }^{28}$ Usp. SCHAEKEN; BIRNBAUM 1999.

${ }^{29}$ Usp. PANTELIĆ 1985: 5.

${ }^{30}$ Usp. MOHLBERG 1928: 216.

31 Vidi: JAGIĆ 1890.

${ }^{32}$ Usp. MOHLBERG 1928: 216.

${ }^{33}$ Usp. MOHLBERG 1928: 213. »In altre parole nel prototipo dei fogli glagolitici di Kiew ritroviamo l'autentico Sacramentario di Gregorio Magno. Ciò è di grande momento per la storia della liturgia occidentale; ma è di immenso valore per la storia della liturgia slava e dei suoi padri Cirillo e Metodio.« (MOHLBERG 1928: 220).

${ }^{34}$ Usp. ŽAGAR 2005: 149.
} 
Štefanić koji ga je pronašao 1956. godine u Kaptolskom arhivu u Splitu pod brojem 468. Štefanić ga je opisao kao fragment misala. U sadržaju ima euhološke tekstove, ali i tekstove Svetoga pisma. Fragment je pergamentni folij dimenzija $30 \times 22 \mathrm{~cm}$, dvostupčani tekst s 29 redaka. Datiran je prema paleografskim oznakama na početak 13. stoljeća. ${ }^{35}$

Vatikanski misal Illirico $4\left(\text { MVat }_{4}\right)^{36}$ najstariji je cjeloviti sačuvani hrvatskoglagoljski misal, koji se već prema incipitu tipološki određuje kao missale secundum consuetudinem Romanae curiae. Kao godinu nastanka neki znanstvenici pretpostavljaju $1372 .{ }^{37} \mathrm{Za}$ sada je dovoljno istaknuti njegovu dataciju na početak 14. stoljeća. $^{38}$

Misal je cjelovito sačuvan, a sadrži sve liturgijske i euhološke elemente kao i latinski misali istoga tipa. S obzirom da predstavlja završetak evolucije rimskih liturgijskih knjiga, u ovom istraživanju služi kao usporedni materijal kojemu je cilj ukazati na kontinuitet euholoških obrazaca starocrkvenoslavenskih euholoških tekstova.

\section{POVIJESNO-KOMPARATIVNO ISTRAŽIVANJE}

Istraživanje povijesti rane crkvenoslavenske liturgije, odnosa s latinskim sakramentarima i njihova utjecaja na crkvenoslavenske liturgijske fragmente od 9. do 13. stoljeća proveli smo primijenivši povijesno-komparativnu analizu liturgijskih tekstova. Povijesno-komparativna analiza liturgijskih tekstova već se više godina rabi u istraživanjima povijesti liturgije. Riječ je o metodologiji koja je uspostavljana u više istraživačkih pothvata tijekom zadnjih nekoliko desetljeća te je donijela vrijedne znanstvene rezultate. ${ }^{39} \mathrm{Za}$ potrebe naših istraživanja prilagodili smo je građi starocrkvenoslavenske i hrvatskoglagoljske liturgijske tradicije.

Za razliku od latinske liturgijske tradicije, povijesno-komparativna analiza kao istraživačka metoda uzima u obzir posebnosti crkvenoslavenske liturgijske tradicije poput pisma i jezika, nastanka tekstova i njihove uporabe.

\footnotetext{
35 Također vidi ŠTEFANIĆ 1957: 132: »Tragovi latinizatorske tendencije u Spl. također se dobro smještaju u prvu polovicu XIII. st., u doba mnogovrsnih pokušaja da se u Bosni i bosanskoj crkvi uspostavi auktoritet rimske crkve."

${ }^{36}$ Misal je znanstveno obradio Josef Vajs. Vidi VAJS 1948.

${ }^{37}$ Usp. BAŠIĆ 2006/2007: 93-99.

${ }^{38}$ Usp. VAJS 1948: 56.

${ }^{39}$ Metodologija primijenjena u istraživanjima temelji se na metodologiji istraživanja latinskih liturgijskih tekstova. Vidi više DE ZAN 1995: 12-21 i DE ZAN 1997: 331-365.
} 
$\mathrm{U}$ istraživanju ranoga razdoblja crkvenoslavenske liturgije na temelju spomenute metodologije pokazat ćemo povijesno-komparativnu analizu na primjeru Kijevskih listića, ${ }^{40}$ Bečkih listića ${ }^{41}$ te Splitskoga odlomka misala ${ }^{42}$ koji sadrže euhološke formule koje smo obrađivali. Euhološke formule, tj. molitve u latinskoj tradiciji zvane collecta, secreta ili super oblata, oratio post communionem ili ad complendum, s predslovljem tvore euhološki formular. ${ }^{43}$ Tekst izvornika u istraživanju uspoređujemo $\mathrm{s}$ latinskim tekstom iz tradicije sakramentara te $u$ tekstološkoj i liturgijskoj tradiciji tražimo kontinuitet u sadržaju misala.

\subsection{Kijevski listići (FgKij)}

Iz FgKij ${ }^{44}$ donosimo primjer na blagdanu sv. Klementa Rimskoga i na prvom formularu misa za dane u tjednu.

${ }^{40}$ Bibliografija za FgKij: MOHLBERG 1928; SCHAEKEN 1987; WEINGART; KURZ 1949; GAMBER 1964.

${ }^{41}$ Bibliografija za FgVind: JAGIĆ 1890; WEINGART 1938: 105-129; 233-245.

42 Bibliografija za FgSpal: ŠTEFANIĆ 1957: 54-133.

$43 »$ Liturgical text may be divided into two main groups: biblical texts (Scripture readings, psalms, and biblical songs) and texts composed by the Church (patristic, euchological, poetic, rubrical). Here we are interested in euchological texts, which may be divided into minor euchology (brief and simple texts: opening prayer, prayer over the gifts, prayer after Communion, prayer over the people, psalm prayers, etc.) and major euchology (longer and more elaborate texts: prefaces, Eucharistic Prayers, solemn blessings, etc.). A single euchological text is called a formula (e.g., opening prayer), while an organic body of several euchological texts is called a formulary (e.g., entrance antiphon, opening prayer, prayer over the gifts, Communion antiphon, prayer after Communion). In our study of the Church's euchological heritage, we must distinguish between the euchological deposit (euchology of the past) and contemporary euchology (euchology of the conciliar reform). « (DE ZAN 1997: 341). Euhologij je neologizam iz grčkoga jezika, euchē 'molitva' i logos 'riječ, govor'. AUGÉ 2001: 761 navodi: »Propriamente significa la scienza che studia le preghiere e le leggi che governano la loro formulazione $\mathrm{o}$, come dice lo Zingarelli, la 'dottrina che riguarda la preghiera e le sue forme'. In senso meno proprio, ma ormai di uso corrente, 1 'eucologia' è l'insieme delle preghiere contenute in un formulario liturgico, in un libro o, in genere, nei libri di una tradizione liturgica. L'insieme di questi testi si chiama anche 'deposito eucologico'. In questa sede ci referiamo alle formule di prehiera liturgica in senso stretto, non alle formule liturgiche in genere (inni, antifone, responsori ecc.). (...) Le formule eucologiche si distinguono da tutti $\mathrm{i}$ testi biblici anzituto per la diversità di origine. Le prime infatti sono state create appositamente dalla chiesa per esprimere il mistero del culto in un linguaggio di preghiera, dunque in un linguaggio che è molto vicino alle condizioni socio-culturali dell'assemblea. L'eucologia delle varie tradizioni liturgiche è perciò la manifestazione più caratteristica della concezione che una determinata chiesa locale ha riguardo alla liturgia e al suo mistero."

${ }^{44}$ Transliteracija FgKij preuzeta je prema HAMM 1979: 42-61, s izmjenom u transliteraciji jata koji je preslovljen kao $\hat{e}$ (u Hamma se on prenosi kao $\hat{e}$ i $\check{e}$ ). 


\subsubsection{Primjer: Usporedba FgKij-latinska tradicija}

\begin{tabular}{|c|c|c|}
\hline Broj & Izvorni tekst & Latinski tekst \\
\hline $\begin{array}{l}\text { I.1. } \\
\text { f. } 1 \mathrm{v}\end{array}$ & 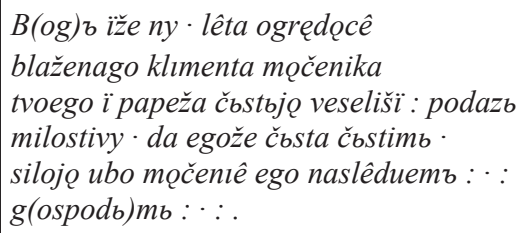 & $\begin{array}{l}\text { Deus qui nos annua beati Clementis } \\
\text { martyris tui atque pontificis solemnitate } \\
\text { laetificas, concede propitius, ut cuius } \\
\text { natalitia colimus uirtutem quoque } \\
\text { passionis imitemur, per dominum. } \\
\text { Gr-P 755; MR 400; Gr-H } 754\end{array}$ \\
\hline I. 2 . & $\begin{array}{l}\text { NADb OPLATMb } \\
\text { Rovanıę g(ospod)i prinesenyę } \\
\text { svęti : i hodataęcju blaženumu klımentu } \\
\text { močeniku tvoemu } \cdot \text { simb ny otb grêhb } \\
\text { skvrbnosti našïh očisti : g(ospodb)mb : }\end{array}$ & $\begin{array}{l}\text { Munera domine oblata santifica, et } \\
\text { intercedente beato Clemente martyre tuo } \\
\text { per haec nos a peccatorum nostrorum } \\
\text { maculis emunda, per dominum. } \\
\text { Gr-P 756; MR } 723\end{array}$ \\
\hline $\begin{array}{l}\text { I. } 3 . \\
\text { f. } 2 r\end{array}$ & 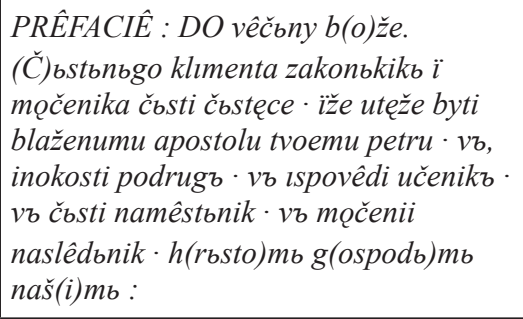 & $\begin{array}{l}\text { UD aeterne Deus. Veneranda Clementis } \\
\text { sacerdotis et martyris solemnia } \\
\text { recurrentes, quifieri meruit beati Petri } \\
\text { in peregrinatione comes, in confessione } \\
\text { discipulus in honore succesor, in passione } \\
\text { secutor, per Christum. } \\
\text { Gr-P } 757\end{array}$ \\
\hline I. 4 . & 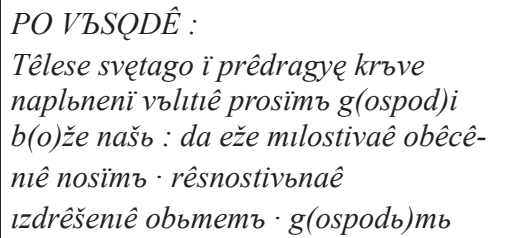 & $\begin{array}{l}\text { Corporis sacri et pretiosi sanguinis } \\
\text { repleti libamine quaesumus domine Deus } \\
\text { noster, ut quod pia deuotione gerimus, } \\
\text { certa redemptione capiamus, per. } \\
\text { Gr-P 758; MR 150; Gr-H } 756\end{array}$ \\
\hline II.1. & 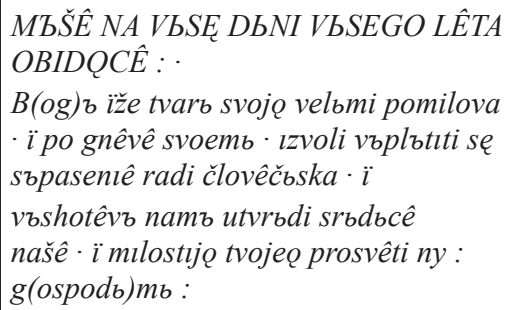 & $\begin{array}{l}\text { Incipiunt orationes cottidianae Gregorii } \\
\text { Papae } 46 \\
\text { Deus qui creature tuae misereri potius } \\
\text { eligis quam irasci cordis nostri infirma } \\
\text { considera, et tuae nos gratia pietatis } \\
\text { inlustra, per. } \\
\text { Gr-P } 849\end{array}$ \\
\hline
\end{tabular}

${ }^{45}$ Naslov skupine euholoških obrazaca u Gr-P. Identične molitve nalaze se i u kodeksu iz Sankt Galena. Budući da im ne nalazimo tekstnu tradiciju u MVat ${ }_{4}$, radi komparacije donosimo latinski tekst prema Gr-P. Gr-H i Ge te Gr-H-Sup imaju drugačiju euhološku tradiciju. U GrH- Sup nalaze se euhološki obrasci, ali sličnost je s molitvama sporadična. Razlika između Gr-P i FgKij jest u broju obrazaca: FgKij navode šest, a Gr-P sedam, dok je u Ge tradiciji također navedeno šest euholoških obrazaca. 


\begin{tabular}{|c|c|c|}
\hline Broj & Izvorni tekst & Latinski tekst \\
\hline II. 2 . & 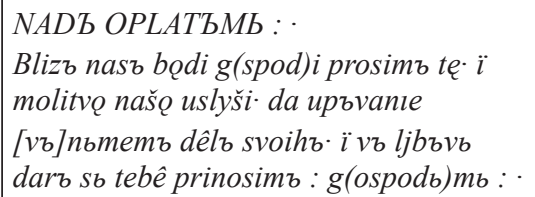 & $\begin{array}{l}\text { Adesto nobis quaesumus domine, et } \\
\text { preces nostras benignus exaudi, ut quod } \\
\text { fiducia non habet meritorum, plactationis } \\
\text { obtineat hostiarum, per. } \\
\text { Gr-P 850; Gr-H-Sup } 1203\end{array}$ \\
\hline $\begin{array}{l}\text { II. } 3 . \\
\text { f. } 3 r\end{array}$ & 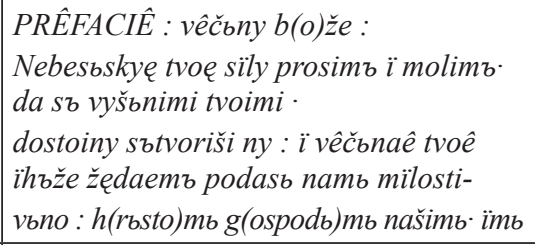 & $\begin{array}{l}\text { UD aeterne Deus. Maiestatem tuam } \\
\text { supliciter deprecantes ut opem tuam } \\
\text { petentibus dignanter impendas, et deside- } \\
\text { rantibus benignus tribuas profutura, per } \\
\text { Christum. } \\
\text { Gr-P 851; Gr-H-Sup } 1632\end{array}$ \\
\hline II.4. & $\begin{array}{l}\text { PO VbSQDÊ: . } \\
\text { Prosimb tę g(ospod)i dazb namb. } \\
\text { da svęty tvoi vbsQdb priemljoce dostoini } \\
\text { bodemb očiščentê tvoego. } \\
\text { ï vêra tvoê vb nasb da vbzdrastetb : } \\
\text { g(ospodb)mb našimb is(uhrbsto)m. }\end{array}$ & $\begin{array}{l}\text { Praesta quaesumus domine ut sancta } \\
\text { tua nos expient, dignosque semper sui } \\
\text { perceptione perficiant, per. } \\
\text { Gr-P } 852\end{array}$ \\
\hline
\end{tabular}

\subsubsection{Primjer: Usporedba FgKij-MVat}

\begin{tabular}{|c|c|c|}
\hline Broj & Izvorni tekst & MVat $_{4}$ \\
\hline $\begin{array}{l}\text { I.1. } \\
\text { f. } 1 \mathrm{v}\end{array}$ & $\begin{array}{l}\text { B(og)b ïže ny } \cdot \text { lêta ogrędocê } \\
\text { blaženago klımenta močenika tvoego } \ddot{i} \\
\text { papeža čbstbjo veselišĭ : podazb milostivy } \\
\cdot \text { da egože čbsta čbstimb } \cdot \text { silojo ubo } \\
\text { močentê ego naslêdue- } \\
\text { mъ : : g g(ospodb)mb }: \cdot{ }^{47}\end{array}$ & $\begin{array}{l}\text { B(ož)e iže ni ophodnim' b(la)ž(e) } \\
\text { nago klim 'nta m(u)č(eni)ka tvoego i } \\
\text { arhierêê prazdnikom'veseliši. podai } \\
\text { m(i)l(o)stive. da egože rožd'stvo čtem'. } \\
\text { Silu ubo muki ego da naslê } \\
\text { duem'. g(ospode)mb. }{ }^{48}\end{array}$ \\
\hline I. 2 . & $\begin{array}{l}\text { NADb OPLATMb } \\
\text { Rovanię g(ospod)i prinesenyę } \\
\text { svęti : i hodataęcju blaženumu klımentu } \\
\text { močenıku tvoemu } \text { simb ny otb grêhb } \\
\text { skvrbnostii našihb očisti : g(ospodb)mb :49 }\end{array}$ & $\begin{array}{l}N(a) d \text { (prinosi) } \\
\text { Dari tebê g(ospod)i prinesenie s(ve)ti } \\
\text { i hodatâ̂cu b(la)ž(e)nomu klim'ntu } \\
\text { m(u)č(eni)ku tvoemu. simi nasb ot } \\
\text { grêhb naših'skvr'n'očisti. }{ }^{50}\end{array}$ \\
\hline
\end{tabular}

${ }^{46}$ Deus qui nos annua beati Clementis martyris tui atque pontificis solemnitate laetificas, concede propitius, ut cuius natalitia colimus uirtutem quoque passionis imitemur, per dominum (Gr-P 755; MR 400; Gr-H 754).

${ }^{47}$ MVat $_{4}$ f. 233b; jednaka molitva kao u FgKij.

${ }^{48}$ Munera domine oblata santifica, et intercedente beato Clemente martyre tuo per haec nos a peccatorum nostrorum maculis emunda, per dominum. Gr-P 756; MR 723 donosi drugačiju molitvu na Rođenje Gospodinovo te upućuje i na sv. Klementa I.; Gr-H 755.

${ }^{49}$ MVat $_{4}$ f. 223b/223c; jednaka molitva kao u FgKij. 


\begin{tabular}{|c|c|c|}
\hline Broj & Izvorni tekst & MVat $_{4}$ \\
\hline f. $2 r$ & 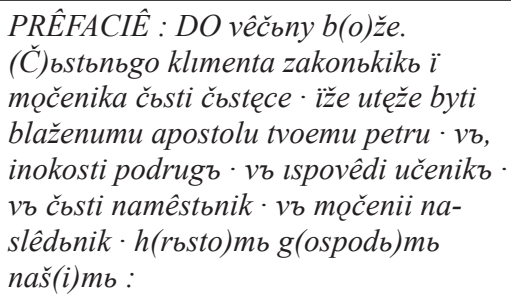 & Nema usporednoga teksta u MVat ${ }_{4}$. \\
\hline I.4. & 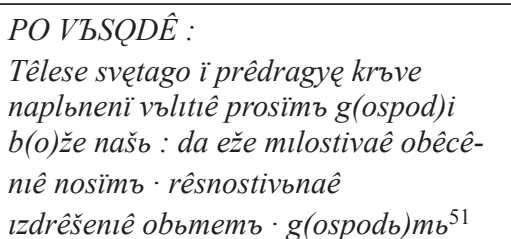 & $\begin{array}{l}\text { Po (brašanci) } \\
\text { Têlese s(ve)t(a)go i prêč́stnie krbvi } \\
\text { napl'neni žr 'tvôu. m(o)l(im) te g(ospod)i } \\
\text { b(ož)e naš'. da eže čistim'obêtovaniem, } \\
\text { tvorim'. istin'nim' obêtovaniem'da } \\
\text { primem'. têmž(de). }{ }^{52}\end{array}$ \\
\hline
\end{tabular}

Na ovom primjeru vidi se atribucija euholoških formula Padovanskomu sakramentaru, ali i grgurovsko-hadrijanskoj tradiciji - dakle starijemu stratumu euholoških obrazaca. Tip sakramentara koji je bio identičan Padovanskomu prepisuje se s početka 8 . stoljeća na području sjeverne Italije i prekoalpskih zemalja te se može pretpostaviti da je ta tipologija sakramentara u dodirnom području sa slavenskim kršćanskim narodima. Također, Padovanski je sakramentar tip Gregoriana mixta - te sadrži i miješani stratum euholoških obrazaca. Iz primjera je vidljivo da je samo euhološki formular za blagdan sv. Klementa u tradiciji i transmisiji teksta do $\mathrm{MVat}_{4}$, dok je njegova latinska atribucija u Padovanskom sakramentaru kao i u starijoj grgurovskoj tradiciji.

Mise za dane u tjednu (orationes cottidianae Gregorii papae, dijelovi II, 1-4) nismo našli u usporednom tekstu misala MVat ${ }_{4}$. Ta činjenica ne dotiče se toliko starocrkvenoslavenske tradicije koliko latinske tradicije euholoških tekstova koji su iz sakramentara preneseni u misale.

\subsection{Bečki listići (FgVind)}

FgVind s početka 12. stoljeća, kao najstariji hrvatskoglagoljski liturgijski spomenik, sadrži također identičnu tekstološku i liturgijsku podlogu s latinskim rimskim sakramentarima. U odnosu na FgKij, FgVind imaju stariji stratum euholoških formula, koji su vjerojatno prepisivani na sjevernotalijan-

\footnotetext{
${ }^{50}$ Corporis sacri et pretiosi sanguinis repleti libamine quaesumus domine Deus noster, ut quod pia deuotione gerimus, certa redemptione capiamus, per. (Gr-P 758; MR 150; Gr-H 756).

${ }^{51} \mathrm{MVat}_{4}$ f. 223c; jednaka molitva kao u FgKij.
} 
skom području, tj. na dodirnom području sa crkvenoslavenskom liturgijom. Euhološke formule mogu se identificirati u Gr-H, ali je u hrvatskom crkvenoslavenskom prijevodu riječ o leksičkoj prilagodbi latinskih teoloških i liturgijskih izričaja. I ova se dva primjera nalaze u tradiciji i transmisiji teksta do $\mathrm{MVat}_{4}$.

\subsubsection{Primjer: Usporedba FgVind ${ }^{52}$ - latinska tradicija}

\begin{tabular}{|c|c|c|}
\hline & FgVind & Latinska tradicija \\
\hline $\begin{array}{l}\text { I.1. } \\
\text { f. } 1 \mathrm{a}\end{array}$ & $\begin{array}{l}\text { Tainaïa } \\
\text { (da)ri g̃i: eže za čbs(tb apustolb) } \\
\text { tvoihb. prinosimb (milostivb) } \\
\text { (pri)imi : i v'sa zlaê, êže s'tv(ori) } \\
\text { mb: otvrati ot nasb }\end{array}$ & $\begin{array}{l}\text { Super oblata. Munera domine quae pro } \\
\text { apostolorum tuorum illorum solemnitate } \\
\text { deferiumus propitius suscipe, et mala } \\
\text { omnia quae meremur auerte. } \\
\text { Per. Gr-H-Sup } 1225 \text {; Missa in natale } \\
\text { plurimorum apostolorum. }\end{array}$ \\
\hline I. 2 . & $\begin{array}{l}\text { : Po (brašbnbci): } \\
\text { sp(a) senihb nasičb̌́e se ta(i)nb: m(o)limb } \\
\text { te se : da ihbž(e) (p)ametb čtemb : } \\
\text { ap(usto)lb t(vo)ihb : têhb m(o)litvami da } \\
\text { izbavimb se } \text { s. }^{55}\end{array}$ & $\begin{array}{l}\text { Quaesumus domine salutaribus repleti } \\
\text { mysteriis, ut quorum solemnia } \\
\text { celebramus, eorum orationibus } \\
\text { adiunemur. } \\
\text { Per. Gr-H-Sup } 1226 .\end{array}$ \\
\hline
\end{tabular}

\subsubsection{Primjer: Usporedba FgVind-MVat}

\begin{tabular}{|c|c|c|}
\hline & FgVind & MVat $_{4}$ \\
\hline $\begin{array}{l}\text { I.1. } \\
\text { f. } 1 \mathrm{a}\end{array}$ & $\begin{array}{l}\text { Tainaïa } \\
\text { (da)ri g̃i: ě̌e za čbs(tb apustolb) } \\
\text { tvoihb. prinosimb (milostivb) } \\
\text { (pri)imi : i v'sa zlaê, êže s'tv(ori)mb: } \\
\text { otvrati ot nasb }\end{array}$ & $\begin{array}{l}N(a) d \text { (prinosi) } \\
\text { Dari g(ospod)i eže tebê za s(ve)tih' } \\
\text { ap(usto)l'tvoih' prazdniki prinosim, } \\
\text { m(i)l(o) stivê primi. i vsa zbla êže za grêhi } \\
\text { n(a)še trbpim otvrati. }{ }^{57}\end{array}$ \\
\hline
\end{tabular}

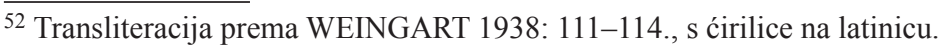

${ }^{53}$ Super oblata. Munera domine quae pro apostolorum tuorum illorum solemnitate deferiumus propitius suscipe, et mala omnia quae meremur auerte. Per. (Gr-H-Sup 1225; Missa in natale plurimorum apostolorum).

${ }^{54}$ Quaesumus domine salutaribus repleti mysteriis, ut quorum solemnia celebramus, eorum orationibus adiunemur. Per. (Gr-H-Sup 1226).

${ }^{55}$ Super oblata. Munera domine quae pro apostolorum tuorum illorum solemnitate deferiumus propitius suscipe, et mala omnia quae meremur auerte. Per. (Gr-H-Sup 1225; Missa in natale plurimorum apostolorum).

${ }^{56} \mathrm{MVat}_{4}$ f. 231d. Misni obrazac slavlja više apostola. (MR 688; Gr-H-Sup 1225).
} 


\begin{tabular}{|c|c|c|}
\hline & FgVind & MVat $_{4}$ \\
\hline I. 2. & $\begin{array}{l}\text { Po (brašbnbci): } \\
\text { sp(a) senihb nasiĉšse se ta(i)nb: } \\
\text { m(o)limb te se : da ihbž(e) (p)ametb } \\
\text { čtemb : ap (ustol)lb t(vo)ihb : têhb } \\
\text { m(o)litvami da izbavimb se } e^{58}\end{array}$ & $\begin{array}{l}\text { po b(rašanci) } \\
\text { Molim te g(ospod)i sp(a) sitelnimi } \\
\text { napl'nivše se dai nami. da ihže prazdniki } \\
\text { ćtem'. ihb m(o)l(i)tvami pomogli se } \\
\text { bihom'. }{ }^{59}\end{array}$ \\
\hline
\end{tabular}

\subsection{Splitski odlomak misala (FgSpal)}

Treći je izvor istraživanja FgSpal koji je tipološki različit od prethodnih spomenika. Riječ je o plenarnom misalu koji je specifičan po svojoj starini, tj. početku 13. stoljeća, te po tekstološkoj različitosti u odnosu na latinske predloške.

\subsubsection{Primjer: Usporedba FgSpal ${ }^{59}$ - latinska tradicija}

\begin{tabular}{|c|c|c|}
\hline II.1. & $\begin{array}{l}M(i) \text { sa } \\
\text { Blaženoga anbrosiê ispovidnika tvoega } i \\
\text { ar[h]ieriê na vsaki d(a)n[b...] } i^{61} \text { n[a](s)b } \\
\text { nasladitb m(o)l(it)va da [e]že naša } \\
\text { nedostoitb s[l]abostb prosêti tb za ni } \\
\text { [h]odatai da budet. g(ospode)m. }\end{array}$ & $\begin{array}{l}\text { Beatus sacerdos et confessor tuus ille } \\
\text { quaesumus domine. sua nos intercessione } \\
\text { apud te commendet: Ut tibi placito fulti } \\
\text { suffragio quam precamur indulgentiam } \\
\text { peccatorum consequi mereamur. per. } \\
\text { Orationes et preces in natale } \\
\text { confessorum, CAL II, br. } 1114 \text {. }\end{array}$ \\
\hline II.2. & 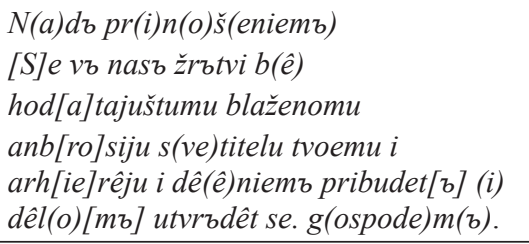 & $\begin{array}{l}\text { Haec hostia qaesumus domine quam in } \\
\text { sollemnitate beati confesoris tui Ambrosii } \\
\text { deferimus. et unicula nostrae prauitatis } \\
\text { absolutat. et tue nobis missericordiae } \\
\text { dona conciliet: per. } \\
\text { CAL II, br. } 42 \text {. }\end{array}$ \\
\hline II.3. & $\begin{array}{l}\text { Po br(a)š(b)n(b)c(i) } \\
\text { [S]e ni komъkan(i)e g(ospod)i očisti } \\
\text { ot grih(b) m(o)l(it)vami [bl]aženoga } \\
\text { arhieriê } i \text { s(ve)titela tvoega anbrosiê } \\
\text { neb(e)skêmb slastemъ stvori bitê } \\
\text { prêčastnikomb. g(ospode)m(b). }\end{array}$ & $\begin{array}{l}\text { Haec nos communio, Domine, purget a } \\
\text { crimine: et caelestis remedii faciat esse } \\
\text { consortes. Per Dominum. } \\
\text { MR } 588\end{array}$ \\
\hline
\end{tabular}

${ }^{57}$ Quaesumus domine salutaribus repleti mysteriis, ut quorum solemnia celebramus, eorum orationibus adiunemur. Per. (Gr-H-Sup 1226).

${ }^{58}$ MVat $_{4}$ f. 231d; MR 930; Gr-H-Sup 1226.

${ }^{59}$ Transliteracija prema ŠTEFANIĆ 1957: 60-61.

$60 » \operatorname{dn}[$ Ђ...]i uništila je rupa u pergameni, a ne raspolažemo tekstom, kojim bi se dala popuniti.« (ŠTEFANIĆ 1957: 60). 


\subsubsection{Primjer: Usporedba FgSpal-MVat ${ }_{4}$}

\begin{tabular}{|c|c|c|}
\hline II.1. & $\begin{array}{l}\text { M(i)sa } \\
\text { Blaženoga anbrosiê ispovidnika tvoega } \\
\text { i ar[h]ieriê na vsaki d(a)n[z..] } n[a](s) \text { b } \\
\text { nasladitъ m(o)l(it)va da [e]že naša } \\
\text { nedostoitb s[l]abostb prosêti tъ za ni } \\
\text { [h]odatai da budet. g(ospode)m. }\end{array}$ & $\begin{array}{l}\text { or(a)c(iê). } \\
\text { Dai prosim'vs(e)m(o)gi b(ož)e. da iže } \\
\text { b(la)ž(ena)go ambroziê isp(o)v(ê)dnika } \\
\text { tvoego i arhierêê čbsti čtem'. ego u tebe } \\
\text { hodataistvi pomogli se bihom'. }{ }^{2}\end{array}$ \\
\hline II. 2. & 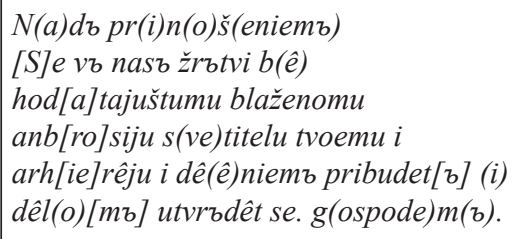 & 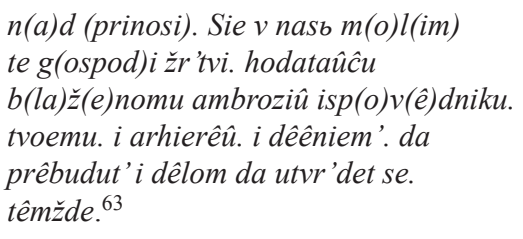 \\
\hline II. 3. & 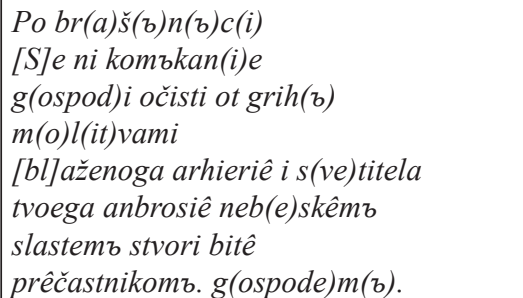 & $\begin{array}{l}\text { po b(rašanci) } \\
\text { Se nasb priêtie. g(ospod)i čisti ot grêhb } \\
\text { i hodataûcu b(la)̌z(e)nomu ambroziûu } \\
\text { isp(o)v(ê)dniku tvoemu i arhierêu. } \\
\text { n(e)b(e)skim'slastem'stvori ni. biti } \\
\text { pričest'niki. }{ }^{64}\end{array}$ \\
\hline
\end{tabular}

Prikazani primjer odnosi se na blagdan sv. Ambrozija, koji izostaje u rimskoj liturgijskoj tradiciji sve do izdanja misala nakon Tridentskoga sabora. Prisutnost čašćenja toga sveca pokazuje ujedno i utjecaj latinskih sakramentara sjeverne Italije na dalmatinsko glagoljaško područje.

$\mathrm{U}$ istraživanju FgSpal nailazimo na nekoliko zanimljivosti i posebnosti u odnosu na latinsku tradiciju. Zanimljivo je da se isti spomen sveca, svetoga Ambrozija, pojavljuje i u MVat ${ }_{4}$, ali s razlikom euholoških formula. Molitva II.1. koja je u MVat ${ }_{4}$ za sv. Ambrozija u Gr-H-Sup 1233 navodi se na In natale unius confessoris, a u MR 187 vlastito je slavlje sv. Hipolita i opće slavlje svetaca (Commune sanctorum. Pro Confessore Pontifice. Missa »Statuit«). Molitva u FgSpal nema paralele u rimskim sakramentarima i misalima te je vjerojatno ambrozijanskoga podrijetla.

${ }^{61} \mathrm{MVat}_{4}$ f. $170 \mathrm{~d}$. Da qaesumus omnipotens deus, ut beati Ill. confessoris tui ueneranda solemnitas, et devotionem nobis augeat et salutem. Per. Gr-H-Sup 1233.

${ }^{62} \mathrm{MVat}_{4}$ f. $171 \mathrm{a}$.

${ }^{63}$ Haec nos communio, Domine, purget a crimine: et caelestis remedii faciat esse consortes. Per Dominum. (MR 588). 
Molitvi II.2. također nismo pronašli usporedbe u latinskim izvornicima. Vjerojatno je riječ o slobodnu prijevodu, a uočljiva je tekstna tradicija FgSpal $-\mathrm{MVat}_{4}$.

Molitva II.3. u MR 588 jest iz Commune sanctorum, Pro Martyre Pontifice i približan je prijevod. Razlika je u tom što $\mathrm{MVat}_{4}$ iz općega obrasca (MR) izostavlja atribuciju svecu mučeniku, a dodaje naslov ispovjedaoca. U Gr-H molitva dolazi na osminu Božića, posvetu biskupa, na sv. Protazija i Gervazija u Gr-H 567 i Gr-P 516. Prijevod je ili preuzet iz ne-rimskoga obreda, vjerojatno ambrozijanskoga, ili je uz prijevod ujedno prisutno i vlastito, hrvatskoglagoljsko priređivanje molitve na temelju latinskoga predloška.

Prema tomu, FgSpal, kao najstariji predstavnik misalske tradicije u hrvatskoglagoljskoj liturgiji, a vjerojatno i crkvenoslavenske liturgije uopće, koji prema sloju svetaca potječe vjerojatno sa srednjodalmatinskoga područja, tj. s područja od Zadra do Makarske i njihova zaleđa, ${ }^{64}$ nastaje pod utjecajem miješane rimsko-ambrozijanske tekstne tradicije. S obzirom na njegovu dataciju nije moguće afilirati ga akvilejskim sakramentarima, ali je očito da je podrijetlo euholoških formula sjevernotalijansko područje.

\section{ZAKLJUČAK}

Istraživanje povijesti crkvenoslavenske liturgije i njezine liturgijske provenijencije pokazuje se mogućim tek na temelju povijesno-komparativne analize liturgijskih tekstova koji dopunjuju lacunae u povijesnim podacima. Povijesni izvori navode postojanje liturgijske tradicije na starocrkvenoslavenskom jeziku, ali ne donose njezinu liturgijsku pripadnost već se osvrću na problematiku liturgijskoga jezika. U crkvenoslavenskim liturgijskim izvorima od 9. do 14. stoljeća do izražaja dolazi rimska liturgijska pripadnost euholoških obrazaca. Ovih tek nekoliko navedenih izvora istraživanja jasno pokazuje da se tekstološka podudarnost nalazi u više tipova sakramentara i misala rimskoga obreda.

Ako se uzme u obzir tekstološka sličnost kao i liturgijska tekstološka kvalifikacija rimskih euhologija, možemo vidjeti da se i u starocrkvenoslavenskim pa i u hrvatskim crkvenoslavenskim prijevodima čuva concinnitas i sobrietas Romana. Iz istraživanja euholoških obrazaca liturgijskih izvora na starocrkvenoslavenskom i hrvatskom crkvenoslavenskom jeziku otkriva se njihova povezanost $\mathrm{s}$ latinskim rimskim liturgijskim izvorima s područja sjeverne Italije i prekoalpskih krajevnih crkava. Zato se i može govoriti o

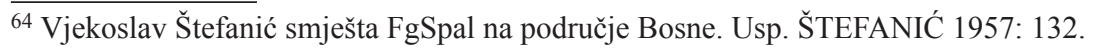


dodirnom području akvilejske crkvene jurisdikcije, salzburške nadbiskupije i krajevnih crkava s moravskim i panonskim područjem, ali i s hrvatskim i dalmatinskim crkvenim područjem.

Ovakvim povijesno-komparativnom istraživanjem starocrkvenoslavenskih i latinskih kao i hrvatskih crkvenoslavenskih i latinskih liturgijskih izvora omogućuje se ulazak liturgijske znanosti u paleoslavistička istraživanja, kao prilog interdisciplinarnomu proučavanju ćirilometodskoga naslijeđa srednje Europe.

\section{IZVORI}

\section{Crkvenoslavenski liturgijski izvori}

FgKij = Kijevski listići, 10.(11./12.st), Ukrajinska nacionalna knjižnica V. I. Vernadsky, Kijev, sign. II 328.

FgVind = Bečki lističi, 11. st., Österreichische Nationalbibliothek (ÖNB), Beč, sign. Cod. Slav. 136.

FgSpal $=$ Splitski fragment misala, 13. st., Kaptolski arhiv, Split, sign. 468.

MVat $_{4}=$ Vatikanski misal Illirico 4, Biblioteca Apostolica Vaticana, Rim, sign. Borg. illir. 4.

\section{Latinski liturgijski izvori}

Ge = Sacramentarium Gelasianum, VIII. st.; MOHLBERG, C. 1918. Das fränkische Sacramentarium Gelasianum in alamannischer Überlieferung (Codex Sangall. No. 348). St. Galler Sakramentar-Forschungen I. Münster: Liturgiegeschichtliche Quellen. Heft 1/2.; MOHLBERG, C. (ur.). 1960. Liber sacramentorum Romanae Ecclesiae ordinis anni circuli. Roma: Herder.

Gr-H = Sacramentarium Gregorianum Hadrianum; DESHUSSES, J. (ur.). 1992. Le Sacramentarire Grégorien. Vol. I. Specilegium Friburguense 16. Fribourg: Éditions universitaires.

Gr-H-Sup = Gregorianum Hadrianum cum supplemetum; DESHUSSES, J. (ur.). 1992. Le Sacramentaire Grégorien. Vol. I. Specilegium Friburguense 16. Fribourg: Éditions universitaires.

Gr-P = Gregorianum, Padouense D 47., VII. st.; MOHLBERG, C.; BAUMSTARK, A. 1967. Die älteste erreichbare Gestalt des Liber Sacramentorum anni circuli der Römischen Kirche. Cod. Pad. D 47, fol. 11r-100r. Liturgiewissenschaftliche Quellen und Forschungen. Heft 11/12. 1927. Reproduktion. Münster: Aschendorff.

MR = Missale Romanum secundum consuetudinem Romanae curiae; BRUYLANTS, P. 1952. Les oraisons du Missel Romain. Texte et Histoire I. Tabulae synopticae fontium Missalis Romani. Indices. Reproduction anastatique 1965. Louvain: Centre de Documentation et d'Information Liturgiques. 
BRUYLANTS, P. 1952. Les oraisons du Missel Romain. Texte et Histoire II. Orationum textus et usus juxta fontes. Reproduction anastatique 1965. Louvain: Centre de Documentation et d'Information Liturgiques.

CAL = HEIMING, O. 1969. Corpus ambrosiano liturgicum II. Das Ambrosianische Sakramentar von Biasca. 1. Teil: Text. Liturgiewissenschaftliche Quellen und Forschungen. Heft 51. Münster: Aschendorff.

\section{Ostalo}

CLLA = GAMBER, K. 1968. Codices liturgici latini antiquiores. Secunda editio aucta. Freiburg: Universitätsverlag Freiburg.

MMFH = Magnae Moraviae Fontes Historici. Vol. II. Textus biographici, hagiographici, liturgici. Editio secunda, rivista et aucta. Universitas Masarykiana Brunensis. Facultas Philosophica. Praha 2010.; Magnae Moraviae Fontes Historici. Vol. III. Diplomata, Epistolae, Textus historici varii. Opera unicersitatis Putkynianae Brunensis, Facultas Philosophica. Brno 1969.

SC = Sacrosactum Concilium. Konstitucija o svetoj liturgiji. Drugi vatikanski koncil. Dokumenti. Kršćanska sadašnjost. Zagreb ${ }^{7} 2008$.

ŽK = Žitije Konstantinovo; GRIVEC, F.; F. TOMŠIĆ. 1960. Constantinus et Methodius Thessalonicenses. Fontes. Radovi Staroslavenskog instituta 4.

ŽM = Žitije Metodovo; GRIVEC, F.; F. TOMŠIĆ. 1960. Constantinus et Methodius Thessalonicenses. Fontes. Radovi Staroslavenskog instituta 4.

\section{LITERATURA}

AUGÉ, M. 1974. Principi di interpretazione dei testi liturgici. B. Neunheuser, S. Marsili, M. Augé, R. Civil (ur.). La Liturgia, momento nella storia della salvezza (Anamnesis 1). Torino: Marietti, 159-179.

AUGÉ, M. 2001. Eucologia. Dizionario di liturgia. D. Sartore, A. M. Triacca, C. Cibien (ur.). Milano: I dizionari San Paolo, Edizioni San Paolo, 761-771.

BAŠIĆ, P. 2006./2007. Kada je napisan hrvatskoglagoljski misal MVat ${ }_{4}$. Slovo 56-57: 93-99.

BETTI, M. 2014. The Making of Christian Moravia (858-882). Brepols: Leiden-Boston.

BIRKFELLNER, G. 1975. Glagolitische und kyrillische Handschrifte in Österreich, I/8. Wien: Verlag der Österreichischen Akademie der Wissenschaften, 54-55.

BIRNBAUM, H.; J. SCHAEKEN. 1999. Die alkirchenslavische Schriftkultur. Altkirchenslavische Studien II. München: Verlag Otto Sagner.

BROVELLI, F. 1989. La storia della liturgia: criteri per la comprensione e lo studio. F. Brovelli (ur.) Il mistero celebrato. Per una metodologia dello studio della liturgia. Roma: Edizioni liturgiche, 107-140. 
DE ZAN, R. 1995. Noti e appunti per una introduzione all'ermeneutica e alla metodologia liturgiche. Dispense »ad usum auditorum privatum«, pro manuscripto. PadovaRoma.

DE ZAN, R. 1997. Criticism and Interpretation of Liturgical Texts. A. J. Chupungco (ur.). Handbook for Liturgical Studies. Vol. I. Collegeville: The Liturgical Press, 331-366.

DIX, G. 1949. The Shape of the Liturgy. Westminster: Dacre Press.

DOSTAL, A. 1965. The Origins of the Slavonic Liturgy. Dumbarton Oaks Papers 19: $67-87$.

DVORNIK, F. 1956. The Slavs. Their Early History and Civilization. Boston: American Academy of Arts and Sciences.

DVORNIK, F. 1970. Byzantine Mission among the Slavs. New Brunswick - New Jersey: Rutgers University Press.

FOLSOM, C. 1997. Liturgical Books of the Roman Rite. A. J. Chupungco (ur.). Handbook for liturgical studies. Vol. I. Collegeville: The Liturgical Press, 245-314.

GAMBER, K. 1964. Die Kiewer Blätter in sakramentargeschichtlicher Sicht. M. Hellmann (ur.). Cyrillo-Methodiana. Zur Frühgeschichte des Christentums bei den Slaven 863-1963. Slavistische Forschungen, Band 6., 362-371.

GAMBER, K. 1966. Das Sakramentar von Salzburg als Quelle für das »Pragense«. Studia Patristica 8, 209-213.

GAMBER, K. 1967. Das Fragment eines glagolitischen Sakramentars in Wien sakramentargeschichtlich untersucht. Geschichte der Ost- und Westkirche in ihren wechselseitigen Beziehungen. Acta Congressus historiae Slavicae Salisburgensis in memoriam SS. Cyrrilli et Methodii anno 1963 celebrati. Wiesbaden: Otto Harrasowitz, 80-83.

GAMBER, K. 1970. Zu einigen liturgischen Termini. Missa Romensis. Studia patristica et liturgica 3: 170-209.

GARZANITI, M. 2007. Slavia latina e Slavia ortodossa. Per un'interpretazione della civiltà slava nell'Europa medievale. Studi Slavistici IV: 29-64.

GARZANITI, M. 2010. Ohrid, Split i pitanje slavenskog jezika u bogoslužju u X. i XI. stoljeću. Slovo 60: 307-334.

HAMM, J. 1974. Staroslavenska gramatika. Zagreb: Školska knjiga.

HAMM, J. 1979. Das Glagolitische Missale von Kiew. Wien: ÖAW.

HEIMING, O. 1984. Liber Sacramentorum Augustodunensis. CCSL 159b. Brepols: Turnhout.

JAGIĆ, V. 1890. Glagolitica. Würdigung neuentdeckter Fragmente. Denkschriften der Kaiserlichen Akademie der Wissenschaften in Wien 38: 1-62.

JUNGMANN, J. A. 2012. The Mass of the Roman Rite: Its Origins and Development (Missarum Sollemnia). Vol. 1. Notre Dame University, Christian Classics.

KOUŘIL, P. (ur.). 2014. Cyrilometodêjská misie a Evropa: 1150 let od př́chodu soluňských bratři na Velkou Moravu. Brno: Archeologický ústav Akademie vêd České republiky.

LUKOVINY, L. 2014. Sakramentárne preklady v systéme eucharistických bohoslužieb najstrších hlaholských rukopisov. Slavica Slovaca 2: 103-120. 
MOHLBERG, C. 1928. Il Messale glagolitico di Kiew (sec. IX) ed il suo prototipo romano del sec. VI-VII. Memorie, Vol. II., Atti della Pontificia Accademia Romana di Archeologia: 207-320.

NEUHEUSER, H. P. 1992. Typologie und Terminologie liturgischer Bücher. Bibliothek 16. Nr.1. Forschung und Praxis: 9-143. URL: http://www.degruyter.com/view/j/ bfup.1992.16.issue-1/issue-files/bfup.1992.16.issue-1.xml (16. 9. 2014.).

NEUNHEUSER, B. 2009. Storia della liturgia attraverso le epoche culturali. Roma: CLV - Edizioni Liturgiche.

OSTROGORSKI, G. 2006. Povijest Bizanta (324. - 1453.). Zagreb: Golden marketing - Tehnička knjiga.

PALLAZO, E. 1998. A History of Liturgical Books from the Beginning to the Thirteenth Century. Collegeville: The Liturgical Press.

PANTELIĆ, A. 1985. O kijevskim i sinajskim listićima. Slovo 35: 5-56.

PANTELIĆ, A. 1986. Tema posljednjeg suda u prefaciji bečkih listića. Slovo 36: 95-110.

PENTKOVSKY, A. 2014. Славянское богослужение архиепископии святителя Мефодия. J. Radić, V. Savić (ur.). Sancti Cyrillus et Methodius et hereditas Slavica litteraria DCCCLXIII-MMXIII. Beograd: Institut za srpski jezik SANU, 25-100.

RIGHETTI, M. 1964. Manuale di storia liturgica. Vol. I-IV. Milano: Ancora.

SCHAEKEN, J. 1987. Die Kiever Blätter. Studies in Slavic and General Linguistics. Vol. 9. Amsterdam: Rodopi.

SCHNITKER, T. A.; W. A. SLABY. 1983. Concordantia verbalia Missalis Romani. Partes euchologicae. Münster: Aschendorff.

ŠKOVIERA, A. 2007. Liturgia Cyrilometodskej misie na Vel'kej Morave. J. Michalov, P. Ivanič, M. Hetényi, Z. Taneski (ur.). Duchovné, intelektuálne a politické pozadie cyrilometodskej misie pred jej príchodom na Vel'kú Moravu. Nitra: Univerzita Konštantína Filozofa v Nitre, 104-130.

ŠTEFANIĆ, V. 1957. Splitski odlomak misala. Slovo 6-7-8: 54-133.

ŠTEFANIĆ, V. 1969. Glagoljski rukopisi Jugoslavenske akademije. I. dio. M. Kostrenčić (ur.). Zagreb: JAZU.

TANDARIĆ, J. 1980. Hrvatskoglagoljski ritual. Slovo 30: 17-87.

VAJS, J. 1948. Najstariji hrvatskoglagolski misal: s bibliografskim opisima svih hrvatskoglagolskih misala. Zagreb: JAZU.

WEINGART, M. 1949. Texte ke studiu jazyka a písmenictví staroslovênského. J. Kurz (ur.). Praha: Slovanský semináŕ Karlovy university, 114-138.

WEINGART, M. 1938. Hlaholské listy vídeňské. Časopis pro moderní filologii 2: 105129.

ŽAGAR, M. 2005. Grafolingvistički opis bečkih listića. N. Budak (ur.). Raukarov zbornik. Zbornik u čast Tomislava Raukara. Zagreb: FF Press, 143-155. 


\title{
Summary
}

\author{
Kristijan Kuhar
}

\section{THE INFLUENCE OF THE LATIN ROMAN SACRAMENTARIES ON THE CHURCH SLAVONIC ROMAN LITURGY (9th-14th CENTURY)}

The liturgical texts of the Church Slavonic sacramentaries (Kiev Leaflets, Vienna Leaflets, Sinai missal Sin. Slav. $5 N$ and others) from the early stages of the Slavic liturgy (9th to 14th century) with its textological and euchological content mostly belong to the Roman rite. These texts are euchological texts with proper liturgical function: texts are written and arranged for the celebration of the Mass and they are preserved in the liturgical book called sacramentary.

The medieval Latin liturgical textological tradition is divided into two branches: Gelasian and Gregorian, which formed a unique textological tradition in parts of Northern Italy and Transalpine countries (from Aquileia to Salzburg) establishing a new textological tradition known as the »Gelasianized-Gregorian Sacramentary«, which was used in the mentioned parts of Central Europe.

Based on the research of the history of Old Church Slavonic liturgy and historical and comparative analysis of Latin and Church Slavonic texts, mostly conducted for the doctoral thesis entitled Historical and liturgical peculiarities of the early stages of the Slavonic liturgy, this study presents influences of Latin liturgical textological tradition from Central Europe on the oldest Church Slavonic translations of sacramentaries from 9th to 14th century and other liturgical texts, mainly euchological, which continued to exist in the Croatian Glagolitic tradition even after the liturgical reform at the end of the 13th century.

Keywords: Church Slavonic liturgy, Croatian Church Slavonic language, Roman rite, Kiev Leaflets, Vatican Missal Illirico 4 